\title{
PENGELOLAAN KEUANGAN DAN ASET DESA DALAM RANGKA MEWUJUDKAN KEMANDIRIAN UNDANG-UNDANG NOMOR 6 TAHUN 2014 TENTANG DESA
}

\author{
: Suwarso
}

\author{
(SMA Negeri Baturaden, Banyumas)
}

\begin{abstract}
Financial management dfan asset village embodies self-sufficiency based on law No. 6 of the year 2014. The method in this research, methods of juridical normative approach, type of juridical normative research, data sources that are used are the primary law and secondary law materials, and analysis in qualitative analysis.

Self-reliance is a process that the Government of the village to perform activities in order to meet the needs with the capabilities of its own. In order to meet the needs of mandiridapat bias village itself does not always depend on the Government, the village must have authority. The authority which granted the village ACT became the basis for the village to action. Financial and asset management of village based on law No. 6 Year 2014 may push embody independence village. Hope fore the laws not only able to push the manifest independence village, but was able to realize self-reliance village. Independence village should be understood that the village was not left alone without the help of the Government/local government or village could be felt themselves do not need government/local government. Whatever the term independence the village or the village existence definitely self-contained villages should remain within the framework of the unitary State of the Republic with its.
\end{abstract}

Keywords: authority, encourage, independence

Abstrak

Pengelolaan keuangan dfan asset desa mewujudkan kemandirian berdasarkan Undang-undang No. 6 Tahun 2014. Metode dalam penelitian ini, metode pendekatan yuridis normative, tipe penelitian yuridis normative, sumber data yang digunakan adalah bahan hukum primer dan bahan hukum sekunder, dan analisis secara analisis kualitatif.

Kemandirian merupakan suatu proses yang dilakukan pemerintah desa untuk melakukan kegiatan dalam rangka memenuhi kebutuhan dengan kemampuan sendiri. Agar desa bias mandiridapat memenuhi kebutuhan sendiri tidak selalu bergantung pada pemerintah, desa harus mempunyai kewenangan. Wewenang yang diberikan UU Desa menajdi dasar bagi desa untuk bertindak. Pengelolaan keuangan dan asset desa berdasarkan UU No. 6 Tahun 2014 dapat mendorong mewujudkan kemandirian desa. Harapan kedepan undang-undang desa tidak hanya mampu mendorong mewujudkan kemandirian desa, tetapi mampu mewujudkan kemandirian desa. Kemandirian desa harus dipahami bahwa desa tidak dibiarkan sendiri tanpa bantuan pemerintah/pemerintah daerah atau desa menjadi merasa bisa sendiri tidak membutuhkan pemerintah/pemerintah daerah. Apapun istilahnya kemandirian desa atau desa mandiri yang pasti keberadaan desa harus tetap dalam kerangka Negara Kesatuan Republik Indonesai.

Kata kunci: wewenang, mendorong, kemadirian 


\section{A. Pendahuluan}

Penyelenggaraan pemerintahan daerah sesuai dengan Undang-Undang dasar 1945, sebagai konstitusi tertulis di Indonesia dan juga merupakan refleksi dari cita-citas hukum bangsa Indonesia, maka dalam Pasal 18 ayat (1) UUD 1945 disebutkan:

Negara Kesatuan Republik
Indonesia dibagi atas daerah-
daerah provinsi dan daerah-
daerah provinsi itu dibagi atas
kabupaten dan kota, yang tiap-
tiap provinsi, kabupaten dan kota
itu mempunyai pemerintahan
daerah, yang diatur dengan
undang-undang.
Pasal 18B ayat (20 UUD 1945
menyebutkan:
Negara Indonesia mengakui dan
menghormati kesatuan-kesatuan
masyarakat hokum adat beserta
hak-hak tradisionalnya sepanjang
masih hidup dan sesuai dengan
perkembangan masyarakat dan
prinsip Negara Kesatuan Republik
Indonesia yang diatur dalam
undang-undang

Ketentuan tersebut mengandung 2 (dua) hal, yaitu: 1. Pembagian territorial Negara Kesatuan Republik Indonesia terdiri atas daerah provinsi, dan kabupaten/kota.2. setiap daerah memiliki pemerintahan daerahnya masing-masing. Hal ini menunjukkan bahwa pembagian wilayah dan pemerintahan di dalam Negara Kesatuan Republik Indonesai hanya sampai pada wilayah kabupaten/kota. ${ }^{1}$ Berdasarkan hal tersebut maka dapat diasumsikan bahwa sebagai sub sistem pemerintahan di bawah kabupaten/kota maka secara territorial wilayah desa berada di dalam kabupaten/kota. Dengan kata lain, bahwa wilayah atau territorial desa merupakan wilayah yang paling kecil di dalam Negara Kesatuan Republik Indonesia. Hal ini mempertegas dominasi Negara dan pemerintah terhadap keberadaan desa dalam Negara Kesatuan Republik Indonesia, sehingga pengakuan terhadap kemandirian desa berdasarkan susunan asli dan hak asal-usul menjadi sulit untuk diwujudkan. ${ }^{2}$

Mengenai kedudukan desa, menurut Rosjidi Ranggawidjaja, yang menyatakan bahwa pengakuan dan penghormatan Pasal 18 B ayat (2) UUD 1945, kesatuan-kesatuan masyarakat hokum adat serta hak-hak tradisionalnya sepanjang masih hidup dan sesuai dengan perkembangan masyarakat dan prinsip Negara Kesatuan Republik Indonesia yang diatur dalam undangundang. ${ }^{3}$ Landasan ini memisahkan antara satuan pemerintahaan daerah

\footnotetext{
${ }^{1}$ H.W. Wijaya, Otonomi Desa Merupakan Otonomi yang asli, bulat dan utuh, PT. Raja Grafindo Persada, Jakarta, 2004, hlm 4-5.

${ }^{2}$ Ibid, hlm 7

${ }^{3}$ Rosjidi Ranggawidjaja dalam Abdurahman Ali, Pasal 18B ayat (2), Satu Dasa Warsa Perubahan Undangundang dasar 1945, Penerbit Fak. Hukum Unpad, Bandung, 2013, hlm 34.
} 
yang diberi otonomi dengan kesatuan masyarakat hokum. Urusan yang dikelola oleh satuan pemerintahan daerah menunjukkan pemencaran kekuasdaan, sementara sepanjang masih ada, urusan yang dikelola oleh desa merupakan pengakuan, tentunya tetap dimungkinkan terdapat tugas pembantuan yang diberikan oleh pemerintah kabupaten/kota, provinsi maupun pemerintah pusat. ${ }^{4}$

$$
\text { Pada } 15 \text { Januari 2014, }
$$
Pemerintah telah mengundangkan UU. No. 6 Tahun 2014 tentang Desa. Landasan filosofis lahirnya Undangundang tersebut didasarkan kepada pertimbangan bahwa desa memiliki hak asal-usul dan hak tradisional dalam mengatur kepentingan masyarakat setempat dan berperan mewujudkan cita-cita kemerdekaan berdasarkan UUD 1945. Secara yuridis, UU No. 6 Tahun 2014 lahir berdasarkan amanah Pasal 18B ayat (2) UUD 1945.

Dengan diundangkannya UU. No. 6 Tahun 2014 tentang Desa, maka paying hokum terhadap eksistensi keberadaan desa menjadi kuat dan lebih dari itu, desa menjadi subjek pembangunan yang pada saat yang sama desa bukanlah sub system dari pemerintahan kabupaten/kota, melainkan sebagai sub system Negara Kesatuan Republik Indonesia (NKRI).

Keuangan desa dalam Undangundang No. 6 Tahun 2014 tentang
Desa, diatur dalam Pasal 1 angka 10, keuangan desa adalah semua hak dan kewajiban desa yang dapat dinilai dengan uang serta segala sesuatu berupa uang dan barang yang berhubungan dengan pelaksanaan hak dan kewajiban Desa. Pengertian hak dan kewajiban tersebut adalah semua yang menimbulkan pendapatan, belanja, pembiayaan dan pengelolaan keuangan desa. $^{5}$

Sumber pendapatan desa diatur dalam Pasal 72 UU. No. 6 Tahun 2014 tentang desa, pendapatan desa bersumber dari:

a. Pendapatan asli desa terdiri atas hasil usaha, hasil asset, swadaya dan partisipasi, gotong royong dan lain-lain pendapatan asli desa;

b. Alokasi APBN

c. Bagian dari hasil pajak daerah dan retribusi daerah kabupaten/kota

d. Alokasi dana desa yang merupakan bagian dari dana perimbangan yang diterima kabupaten/kota.

e. Bantuan keuangan dari APBD Propinsi, APBD Kabupaten/Kota;

f. Hibah dan sumbangan yang tidak mengikat dari pihak ketiga; dan

g. Lain-lain pendapatan desa yang sah.

Pengelolaan keuangan desa dalam UU. No.6 Tahun 2014 tentang Desa, memberikan penegasan tersendiri pada Bab VIII Keuangan Desa dan Aset Desa, dari Pasal 71 s/d Pasal 77.

\footnotetext{
${ }^{5}$ Ibid, hlm. 4
} 
Untuk mewujudkan pengelolaan keuangan desa tersebut, pemerintah kabupaten/kota diwajibkan membuat Peraturan Kepala Daerah tentang pedoman pengelolaan keuangan desa dan pedoman pengadaan barang/jasa desa.

\section{B. Metode Penelitian}

Metode pendekatan dalam penelitian ini adalah yuridis normative, dengan menggunakan pendekatan perundang-undangan (statute approach). Menurut Pieter Mahmud, pendekatan undang-undang dilakukan dengan menelaah semua regulasi yang bersangkut paut dengan isu hokum yang sedang ditangani.sumber data yang digunakan adalah data sekunder yang terdiri dari bahan-bahan hokum, dan dianalisis secara yuridis kualitatif.

\section{Hasil Penelitian dan Pembahasan}

1. Pengelolaan Keuangan dan Aset Desa dalam mewujudkan Kemandirian berdasarkan Undang-undang Nomor 6 Tahun 2014 tentang Desa.

Kewenangan hak asal usul dan kewenangan local berskala desa yang diberikan UU. No. 6 Tahun 2014, menjadikan desa tidak lagi dijadikan objek, tapi justru menjadi subjek yang akan menentukan nasib desa kedepan.
Kewenangan hak asal usul merupakan warisan yang masih hidup merupakan hak-hak asli masa lalu yang telah ada sebelum Negara Kesatuan Republik Indonesia ada. Pemerintah dan Pemerintah Daerah harus mengakui, menghormati dan melindungi kewenangan hak asal usul desa. Dengan kewenangan hak asal usul yang diberikan kepada desa, desa dapat menggali pendapatan asli desa, memngelola asset-asetnya untuk meningkatkan pendapatan dan kesejahteraan masyarakat desa. Dalam menggali sumber-sumber pendapatan desa, desa dilarang melakukan pungutan atas jasa administrasi, seperti surat pengantar, surat rekomendasi, surat keterangan tetapi desa mempunyai kewenangan untuk melakukan pungutan jasa usaha seperti pemandian umum, wisata desa, pasar desa, tambahan perahu, keramba ikan, pelelangan ikan dan lain-lain.

Kewenangan yang diberikan desa untuk mengelola asset desa dan menggali sumbersumber pendapatan asli desa, akan mendorong desa menjadi mandiri. Kewenangan local berskala desa, menjadikan desa dapat mengatur dan mengurus dirinya sendiri, sehingga desa 


\begin{abstract}
dapat membuat perencanaan pengembangan ekonomi local, perencanaan pembangunan, perencanaan APBDesa, yang sesuai dengan kebutuhan dan keinginan masyarakat desa. Pelaksanaan pembangunan desa dilakukan oleh Pemerintah Desa dengan melibatkan seluruh masyarakat desa dengan semangat kegotong royongan dan dilaksanakan sesuai dengan RKPDesa. Pelaksanaan pembangunan desa dilakukan dengan cara memanfaatkan keuangan desa, asset desa, kearifan local dan sumber daya alam desa yang tersedia.masyarakat desa berhak mendapatkan informasi dan mengawasi pelaksanaan pengelolaan keuangan dan asset desa, serta dapat melaporkan hasil pantauan dan berbagai keluhan terhadap pelaksanaan pembangunan desa kepada Badan Musyawarah desa.
\end{abstract}

$$
\text { Tujuan pengelolaan }
$$

keuangan desa dan asset desa tidak dapat dipisahkan dengan tujuan mewujudkan kesejahteraan dan kemandirian desa. Kepala desa sebagai penanggung jawab pengelolaan keuangan dan asset desa harus dapat mempertanggung jawabkan pelaksanaannya kepada

Bupati/Walikota.

2. Kemampuan pengelolaan dan asset Desa berdasarkan Undang-Undang Na. 6 Tahun 2014 tentang Desa dapat mewujudkan Kemandirian desa.

Pengelolaan keuangan dan asset desa sesuai dengan UU. No. 6 Tahun 2014, mampu mendorong mewujudkan kemandirian desa dalam hal:

a. Desa mampu mengatur dan mengurus dirinya sendiri dengan kekuatan yang dimilikinya. Dengan kewenangan hak asal usul dan kewenangan local berskala desa, desa bias membuat perencanaan pengelolaan asset, kerjasama desa, perencanaan

APBDesa.

b. Pemerintah desa mempunyai kewenangan dalam mengatur dan mengelola pembangunan.

Pemerintah desa dapat membuat perencanaan pembangunan yang 


$\begin{array}{lrl}\begin{array}{l}\text { sesuai dengan } \\ \text { keinginan dan }\end{array} & \begin{array}{l}\text { local berskala desa, desa dapat } \\ \text { kebutuhan masyarakat }\end{array} & \begin{array}{l}\text { pengembangan ekonomi local, } \\ \text { desa. }\end{array} \\ \text { System pemerintahan } & \text { perencanaan pembanagunan, } \\ \text { menjunjung tinggi } & \text { sesuai dengan kebutuhan dan } \\ \text { aspirasi dan partisipasi } & \text { keinginan masyarakat desa. }\end{array}$

masyarakat. Semua unsur masyarakat, pemerintah desa dan BPD

memusyawarahkan

hal-hal yang bersifat

strategis meliputi

penataan desa,

perencanaan desa,

kerjasama desa,

pembentukan

BUNIDesa, pelepasan

dan penambahan asset desa.

d. Sumberdaya

pembangunan dikelola

secara optimal,

transparan dan

akuntabel. Kekayaan

atau aset desa

dilaksanakan

D. Kesimpilan

1. Dengan kewenangan hak asal usul yang diberikan kepada Desa, desa dapat menggali pendapatan asli desa, mengelola assetasetnya untuk meningkatkan pendapatan dan klesejahteraan masyarakat desa. Kewenangann
2. Besarnya dana yang masuk ke Desa terutama dari alokasi dana desa dan dana desa tidak menjadikan desa menunggu atau bergantung pada kucuran dana dari pemerintah/pemerintah daerah tetapi desa harus mampu menggali sumber-sumber pendapatan asli desa, desa harus mempunyai kemampuan membiayai sendiri. Keberadaan UU. No. 6 Tahun 2014 yang diberlakukan sekitar dua tahunan, baru mampu mendorong mewujudkan kemandirian desa, harapan kedepan UU desa tidak hanya mampu mendorobng mewujudkan kemandirian desa, tetapi mampu mewujudkan kemandirian desa. Kemandirian desa harus dipahami bahwa desa tidak dibiarkan sendiri tanpa bantuan dari pemerintah/pemerintah daerah atau desa menjadi merasa bias sendiri tidak membutuhkan keberadaan pemerintah/pemerintah daerah. Apapun istilahbnya kemndirian desa atau desa mandiri yang 
pasti keberadaan desa harus
tetap dalam kerangka Negara
Kesatuan Republik Indonesia

3.

Daftar Pustaka

Budiardjo, Meriam, Dasar-dasar IImu politik, Edisi Revisi Cetakan Keempat, PT. Gramedia Pustaka Utama, Jakarta, 2010.

Fajar, Mukthie, Tipe Negara Hukum, Banyumedia Publishing, Malang, 2004

H.W. Wijaya, Otonomi Desa Merupakan Otonomi yang asli, bulat dan utuh, PT. Raja Grafindo Persada, Jakarta, 2004.

M., Nurhadi, Pengantar Studi Hukum Konstitusi, Cetakan Pertama, Nusamedia, Bandung, 2007.

Rosjidi Ranggawidjaja dalam Abdurahman Ali, Pasal 18B ayat (2), Satu Dasa Warsa Perubahan Undang-undang dasar 1945, Penerbit Fak. Hukum Unpad, Bandung, 2013. 